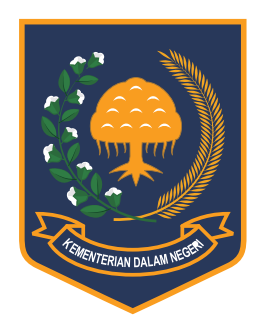

e-ISSN: 2503-3360 | p-ISSN: 2085-4323

Accreditation Number

735/AU2/P2MI-LIPI/04/2016

http://jurnal.kemendagri.go.id/index.php/jbp/index

\title{
ENERgY GOODS DEMAND IN TABALONG REgENCY: AlMOST-IDEAL DEMAND SYSTEM APPROACH
}

\author{
Ahmadi Murjani * \\ BPS-Statistics of Tabalong Regency \\ Jalan Jaksa Agung Soeprapto No. 82 Tanjung, \\ Tabalong Regency, South Kalimantan, Indonesia
}

Received: 18 August 2017; Accepted: 2 November 2017; Published online: 28 November 2017

DOI: $10.21787 / j b p .09 .2017 .307-319$

\begin{abstract}
The declining trend of Tabalong Regency's economic growth in recent years adversely affected the poverty rate. Further, the recent energy subsidy policy applied by the Indonesian Government has pushed the subsidy's budget down for some energy goods. Therefore, there should be an awareness regarding the current energy policy and the impact on the poverty particularly in Tabalong Regency. This paper investigates the demand system for the three main energy goods; premium fuel, electricity, and Liquid Petroleum Gas (LPG) in Tabalong Regency of the South Kalimantan Province. Although the same method was previously used on the different topics, this paper uniquely utilizes the combined Linear Approximation and Quadratic Almost-Ideal Demand System on the particular energy policy topic. This paper utilizes the National Social Economics Survey conducted by BPS-Statistics of Tabalong Regency in 2016. The results show that the income elasticity of demand for the top $60 \%$ and the bottom $40 \%$ of the income groups were positive; however, slight differences could be seen. For the top $60 \%$ of the income group, the income elasticities of demand were $0.97,1.02$, and 1.08 for premium fuel, electricity, and LPG respectively. On the other hand, the bottom $40 \%$ of the income group had 0.99 , 1.07, and 0.91 of income elasticity of demand for premium, electricity, and LPG. The price elasticity of demand for both income groups had negative signs, which is agreeing with the theoretical demand function. These results indicate that the current energy policy should continue with securing the poor households from the possible effect.
\end{abstract}

Keywords: Tabalong, Price Elasticity of Demand, Income Elasticity of Demand, Quadratic Almost-Ideal Demand System, Demand Analysis

\section{INTRODUCTION}

Tabalong Regency experienced a declining trend of the economic growth in the period 2011 to 2015. Luckily, the Tabalong's economic growth recovered in 2016. After enjoying the highly-sevenpercent growth in 2011, the growth kept declining to $2.36 \%$ in 2015 . This trend, unfortunately, brings an impact on the poverty rate in Tabalong. The headcount index of Tabalong Regency decreased from $6.22 \%$ to $5.83 \%$ in the period 2011 to 2012 but increased in the remaining period of 2012 to 2015 (from $5.83 \%$ to $6.59 \%$ ). In 2016, the increasing economic growth of Tabalong Regency stimulated a good impact on the poverty rate. The data showed that the 3.06-percent economic growth in 2016 affected the social condition in Tabalong which led to a decreasing headcount ratio into $6.35 \%$ (Statistics of Tabalong Regency, 2017).

The above situation should become a primary concern for the policymakers in Tabalong regarding the recent policy, particularly the energy subsidy policy that was initiated by the previous Indonesian Government. Indonesian Government has been gradually decreasing its energy subsidy due to the budget deficit and reallocation of funds from 2014 to 2017 (Direktorat Penyusunan APBN \& Direktorat Jenderal Anggaran, 2017).

The energy subsidy comprises of two primary targets: fuel and electricity subsidies. In Indonesia, at the initial phase, there were five products using fuel subsidies: gasoline, kerosene, automotive diesel oil, industrial diesel oil, and fuel oil. As the time changed, and as a part of the energy reform,

\footnotetext{
* Corresponding Author

Phone : +62 85248888473

Email : ahmadimurjani@gmail.com
} 
from 2005, only three products received the fuel subsidy: gasoline, kerosene, and automotive diesel oil (Dartanto, 2013). In 2007, the fuel subsidy expanded to incorporate liquid petroleum gas (LPG) as a part of the government's conversion program from kerosene to LPG (International Institute for Sustainable Development, 2012).

Based on the previous researches, reducing the energy subsidy will lead to an increase in the poverty rate. Dartanto (2013) utilized a CGEmicrosimulation method on 64,407 SUSENAS samples to observe the impact of removing the fuel subsidies on the poverty rate in Indonesia. By using data from the year 2005, he found that when the fuel subsidies were reduced by $25 \%$, the poverty rate will increase by $0.259 \%$. Another research conducted by Breisinger, Engelke, \& Ecker (2012) used Dynamic-CGE to examine the impact of reducing fuel subsidies on GDP and poverty in Yemen. They found that reducing the fuel subsidies without compensation would lead to increases in poverty rate both in urban and rural areas by $2.6 \%$. However, the adverse impact on the poverty could be counterbalanced by direct transfer to the poorest one-third of all households. Based on these researches, in the deceleration of the economic growth and increasing trend of the poverty rate in Tabalong, the focus will be on the subsidized energy goods which are the main commodities in the energy subsidy policy.

There was some research in Indonesia which investigated the demand system for some goods. Widarjono (2013) modeled the demand system in Indonesia for meat using Almost-Ideal Demand System model. Sulistio, Wirabhuana, \& Wiratama (2017) examined the demand for electricity in Indonesia using Dynamic Modelling method. Mariyono (2017) employed a Linear Functional Form Model to estimate the demand model for tourism in Indonesia. The similar research topic was conducted by Bhakti (2011) using the Linear-Approximation of Almost-Ideal Demand System (LA-AIDS). She examined the demand system for energy goods in Java in the period 2007-2010. Thus, this paper aims to investigate the demand system for three particular energy goods in Tabalong Regency using two models, combining the Linear-Approximation of Almost-Ideal Demand System (LA-AIDS) and Quadratic Almost-Ideal Demand System (QUAIDS). This paper incorporates the demand system for energy goods in Tabalong Regency with the current energy policy by the Indonesian Government to produce the policy recommendation for the local government of Tabalong Regency related to the energy consumption.

The second part of this paper is the methodology, which comprises the data selection and model specification. The third part of this paper is results and discussion, and the last part is conclusions.

\section{A. Energy Consumption Profile in Tabalong Regency}

National Social Economic Survey (Susenas) produces the households' consumption data. Based on the data, this paper tabulates the energy goods consumption into two basic tables (Table 1 and Table 2) to analyze the energy consumption profile in Tabalong Regency.

Table 1 tabulates the energy goods spending pattern on particular consumption decision. Hence, this table provides information regarding both the most and the least energy goods consumed by the households regardless the income groups and locations (as the percentages are summed to 100\% vertically, the comparison cannot be made column per column).

Alternatively, Table 2 provides the columns' comparisons for the income groups and locations. However, since the percentages are $100 \%$ in total horizontally, the table can't be compared based on consumption's decision.

\section{1) Energy Goods' Consumption Decision (Table 1 Analysis) \\ Generally, in 2016, households in Tabalong} Regency mostly consumed electricity. Table 1 shows that the households that used electricity reached $99.06 \%$, and only $0.94 \%$ did not have access to electricity. This indicates that Tabalong Regency almost reached full electrification stage.

The second highest energy goods consumed by households in Tabalong Regency was premium fuel. The ease of buying new vehicles using financial lease help to induce the increase in premium fuel usage. Not only that, the premium fuel is one of the energy commodity that is still subsidized by the government until now. In Table 1, 88.38\% of households used premium fuel, only $11.62 \%$ did not consume it in 2016 (or in the period of the survey).

The third highest energy goods consumed by households in Tabalong Regency was LPG. The conversion program initiated by the Indonesian Government in 2007 successfully reduced the usage of kerosene by $80 \%$ in the period 2007 to 2011 (International Institute for Sustainable Development, 2012). The declining usage of kerosene means the households started to shift from kerosene to LPG as a fuel for cooking. Table 1 describes that $73.73 \%$ households in Tabalong Regency used LPG as a cooking fuel, $26.27 \%$ were using other cooking fuel such as kerosene, firewood, etc.

Kerosene became the fourth highest energy goods consumed by the households in Tabalong Regency during 2016. The impact of successful 
Table 1.

Energy Goods Consumption by Income Groups and Location in Tabalong, 2016 (vertical summation in \%)

\begin{tabular}{|c|c|c|c|c|c|c|}
\hline \multirow{2}{*}{$\begin{array}{l}\text { Type of Energy Goods } \\
\text { Consumed }\end{array}$} & & \multicolumn{2}{|c|}{ Income Groups } & \multicolumn{2}{|c|}{ Location } & \multirow{2}{*}{ Total } \\
\hline & & Top 60\% & Bottom 40\% & Urban & Rural & \\
\hline \multirow[t]{2}{*}{ Pertamax Fuel } & yes & 1.77 & 2.68 & 4.86 & 0.37 & 2.09 \\
\hline & no & 98.23 & 97.32 & 95.14 & 99.63 & 97.91 \\
\hline \multirow[t]{2}{*}{ Premium Fuel } & yes & 88.58 & 88.02 & 88.29 & 88.43 & 88.38 \\
\hline & no & 11.42 & 11.98 & 11.71 & 11.57 & 11.62 \\
\hline \multirow[t]{2}{*}{ Electricity } & yes & 99.49 & 98.30 & 99.67 & 98.69 & 99.06 \\
\hline & no & 0.51 & 1.70 & 0.33 & 1.31 & 0.94 \\
\hline \multirow[t]{2}{*}{ LPG } & yes & 72.84 & 75.32 & 85.29 & 66.52 & 73.73 \\
\hline & no & 27.16 & 24.68 & 14.71 & 33.48 & 26.27 \\
\hline \multirow[t]{2}{*}{ Kerosene } & yes & 17.00 & 14.73 & 12.64 & 18.40 & 16.19 \\
\hline & no & 83.00 & 85.27 & 87.36 & 81.60 & 83.81 \\
\hline \multirow[t]{2}{*}{ Automatic Diesel Oil (ADO) } & yes & 3.62 & 0.00 & 1.51 & 2.84 & 2.33 \\
\hline & no & 96.38 & 100.00 & 98.49 & 97.16 & 97.67 \\
\hline
\end{tabular}

Source: Statistics Indonesia, 2016, Author's calculation

kerosene-to-LPG conversion program is the low consumption of kerosene, which was only $16.19 \%$ in 2016.

Automotive Diesel Oil (ADO) is one of the subsidized energy goods in Indonesia. As the fifth highest energy goods consumed in Tabalong Regency, ADO is used mostly by cars. As the nature of these products which is only consumed by the household that owns a car, only $2.33 \%$ of the households in Tabalong Regency consumed it as shown in Table 1.

Pertamax fuel was the least energy goods consumed in Tabalong Regency in 2016. As described in Table 1, only $2.09 \%$ of the households consumed it during 2016.

2) Income Groups and Location (Table 2 Analysis)

In term of locations, as can be seen in Table 2, the households that did not have access to electricity were located in both urban areas (13.47\%) and rural areas (86.53\%). On the other hand, Table 2 also shows that those households without electricity comprised of $35.11 \%$ from the top $60 \%$ and $64.89 \%$ of the income groups.

For premium fuel, the percentage of households that consumed premium in the rural areas was more than in the urban areas, which were $61.64 \%$ and $38.36 \%$ respectively. This means the access for premium fuel is not only in urban areas but also in rural areas. Furthermore, this figure described that the ease of obtaining vehicles reached all areas. A different figure appeared in term of income groups' access to premium fuel shown in Table 2, 64.47\% of households in the $60 \%$ of the income group consumed more premium fuel compared with the households from the bottom $40 \%$ of the income group (35.53\%). Again, this means the wealthier households consume more premiums fuels for vehicles. This evidence supports the previous findings that proved fuel subsidy is consumed mostly by the wealthier household Rohac (2013).

In Table 2, LPG was mostly consumed in the rural areas (55.57\% of households); and in term of income group, $63.56 \%$ of the households from the top $60 \%$ of the income groups used LPG as a cooking fuel. The figure implies that the proportion of households that used LPG is more in the rural area; however, the top $60 \%$ of the income group had a higher proportion to use LPG. This means, in term of proportion, households in the rural areas had easy access to LPG, and the top $60 \%$ of the income group also possessed the higher portion.

Table 2 shows that the rural areas shared $70.01 \%$ of kerosene consumption whereas the urban area had $29.99 \%$ of share. Interestingly, the households from the top $60 \%$ of the income 
Table 2.

Energy Goods' Consumption by Income Groups and Location in Tabalong, 2016 (horizontal summation in \%)

\begin{tabular}{|c|c|c|c|c|c|c|}
\hline \multirow{2}{*}{$\begin{array}{l}\text { Type of Energy Goods } \\
\text { Consumed }\end{array}$} & & \multicolumn{2}{|c|}{ Income Groups } & \multicolumn{2}{|c|}{ Location } & \multirow{2}{*}{ Total } \\
\hline & & Top 60\% & Bottom $40 \%$ & Urban & Rural & \\
\hline \multirow[t]{2}{*}{ Pertamax Fuel } & yes & 54.31 & 45.69 & 89.14 & 10.86 & 100.00 \\
\hline & no & 64.54 & 35.46 & 37.32 & 62.68 & 100.00 \\
\hline \multirow[t]{2}{*}{ Premium Fuel } & yes & 64.47 & 35.53 & 38.36 & 61.64 & 100.00 \\
\hline & no & 63.23 & 36.77 & 38.70 & 61.30 & 100.00 \\
\hline \multirow[t]{2}{*}{ Electricity } & yes & 64.61 & 35.39 & 38.64 & 61.36 & 100.00 \\
\hline & no & 35.11 & 64.89 & 13.47 & 86.53 & 100.00 \\
\hline \multirow[t]{2}{*}{ LPG } & yes & 63.56 & 36.44 & 44.43 & 55.57 & 100.00 \\
\hline & no & 66.49 & 33.51 & 21.50 & 78.50 & 100.00 \\
\hline \multirow[t]{2}{*}{ Kerosene } & yes & 67.54 & 32.46 & 29.99 & 70.01 & 100.00 \\
\hline & no & 63.71 & 36.29 & 40.03 & 59.97 & 100.00 \\
\hline \multirow[t]{2}{*}{ Automatic Diesel Oil (ADO) } & yes & 100.00 & 0.00 & 24.88 & 75.12 & 100.00 \\
\hline & no & 63.48 & 36.52 & 38.72 & 61.28 & 100.00 \\
\hline
\end{tabular}

Source: Statistics Indonesia, 2016, Author's calculation

group consumed more kerosene. $32.46 \%$ of the households from the bottom $40 \%$ of the income group consumed less which proves that kerosene subsidy is not fully absorbed by the main target of the subsidy.

Table 2 depicts that $100 \%$ of the households that consumed ADO came from the top $60 \%$ of the income group, which was mostly located in the rural areas by $75.12 \%$. In term of the recipient of the ADO subsidy, this subsidy was mostly absorbed by the higher income households.

For the Pertamax fuel, most of the consumers were located in the urban areas (89.14\%). In term of the income groups, the consumption was about the same, but the higher consumption went to the top $60 \%$ of the income group by $54.31 \%$.

\section{B. Demand System: Theoretical Background}

\section{1) Effect of Income and Price Changes to the Consumer's Demand}

Nicholson \& Snyder (2011) explained the possible effect regarding the changes in consumer's income and goods' price. The first effect was the demand changes regarding the income. For the normal goods, the higher income would bring the higher demand for the goods because the consumers would maximize their spending (the higher budget, the more bundle of goods consumed). However, this assumption was different in the case of inferior goods. The higher income would create the shifting priority for the consumers. The consumers picked the higher quality goods rather than spending more on the inferior goods.

The second effect was the demand changes regarding the price of the goods. Generally, the higher price of particular goods would decrease the demand for it. The situation could be different in some cases. For the necessity and addictive goods, the demand for it would not change so significantly when the price changes. On the other hand, the goods without any close substitutes would follow the normal goods' demand behavior to the price changes. The changing price of the complementary goods also determined the demand for the paired goods, for example: when the price of sugar decreased, the demand for tea would increase (the lower price of sugar, the more demand for sugar and tea).

\section{2) Nature of Demand}

The utility is an economics concept that explains the consumers' satisfaction from consuming goods and services. A normal consumer will choose a basket of goods and services to achieve 
the highest utility level. Based on these concepts, the researcher can derive a demand system and estimate the demand function to obtain the estimation parameters. Eventually, the researcher can predict the consumers' behavior in term of demand. Next equations are the nature of demand function that explains the households' behavior in consuming goods and services (Widarjono, 2016).

Mathematically, consumers maximize their utility related to the prices and the quantities of goods and services. The relation can be written as:

$$
\operatorname{Max} \mathrm{U}=\sum_{i=1}^{n} p_{i} q_{i}=I
$$

where $\mathrm{U}$ is utility level, $p$ is the price, $q$ is the quantity consumed, $i$ is the goods and services, and $I$ is the amount of Income.

Using the Lagrangian, the equation (2.1) produces Marshallian demand function:

$$
q_{i}=q_{i}(p, I)
$$

The demand function above describes the relationship between the quantities of goods and services, prices, and income. The quantity demanded will be determined by the prices and the households' income. Using the equation (2.1) and (2.2), the parameters of demand function can be obtained.

The first nature of demand function is adding up. This nature explains that consumers will spend all the income they have, and can be written as:

$$
\begin{aligned}
& p_{1} q_{1}+p_{2} q_{2}+\ldots+p_{n} q_{n}=I \\
& \sum_{i=1}^{n} p_{i} q_{i}(p, I)=I \ldots \ldots \ldots \ldots \ldots \ldots
\end{aligned}
$$

where $p$ is the price, $q$ is the quantity consumed, and $I$ is the consumers' income.

The equation (2.3) can be decomposed written into:

$$
p_{1} q_{1}(p, I)+p_{2} q_{2}(p, I)+\ldots+p_{n} q_{n}(p, I)=I . .
$$

The first order differentiation of equation (2.4) concerning I produces the equations:

$$
p_{1} \frac{\partial q_{1}}{\partial_{1}}+p_{2} \frac{\partial q_{2}}{\partial_{1}}+\cdots+p_{n} \frac{\partial q_{n}}{\partial_{1}}=1
$$

Both sides are multiplied by $\frac{I}{q} \frac{q}{I}$

$$
\begin{aligned}
& p_{1} \frac{\partial q_{1}}{\partial_{1}} \frac{I}{q_{1}} \frac{q_{1}}{I}+p_{2} \frac{\partial q_{2}}{\partial_{1}} \frac{I}{q_{2}} \frac{q_{2}}{I}+\cdots \\
& +p_{n} \frac{\partial q_{n}}{\partial_{1}} \frac{I}{q_{n}} \frac{q_{n}}{I}=1 \frac{I}{q_{1}} \frac{q_{1}}{I} \\
& \frac{p_{1} q_{1}}{I} \frac{\partial q_{1}}{\partial_{1}} \frac{I}{q_{1}}+\frac{p_{2} q_{2}}{I} \frac{\partial q_{2}}{\partial_{1}} \frac{I}{q_{2}}+\cdots \\
& +\frac{p_{n} q_{n}}{I} \frac{\partial q_{n}}{\partial_{1}} \frac{I}{q_{n}}=1 \\
& w_{1} \eta_{1}+w_{2} \eta_{2}+\cdots w_{n} \eta_{n}=1 \\
& \sum_{i=1}^{n} w_{i} \eta_{i}=1
\end{aligned}
$$

Where $w_{i}$ is the budget share, and $\eta_{i}$ is the income elasticity. The equation (2.5) is commonly known as the Engel Aggregation.

The second nature of demand function is homogeneity. If all prices of all goods and services increase while in the same time, incomes also increase with constant level $(\theta)$; therefore, there will not affecton the quantities of all goods and services consumed. The demand function has a homogenousof-degree-zero property. It can be expressed as:

$$
q_{i}\left(\theta_{p} \theta_{I}\right)=q_{i}(p, I)
$$

Using Euler's theorem, the first order differentiation of equation (2.6) satisfies the equation:

$$
p_{1} \frac{\partial_{q_{1}}}{\partial_{p_{1}}}+p_{2} \frac{\partial_{q_{2}}}{\partial_{p_{2}}}+\cdots+p_{n} \frac{\partial_{q_{n}}}{\partial_{p_{n}}}+I \frac{\partial_{q_{n}}}{\partial_{I}}=0
$$

If equation (2.7) is divided by $q_{1}$, then it producess the following equation:

$$
\begin{aligned}
& \frac{p_{1}}{q_{1}} \frac{\partial_{q_{1}}}{\partial_{p_{1}}}+\frac{p_{2}}{q_{1}} \frac{\partial_{q_{2}}}{\partial_{p_{2}}}+\cdots+\frac{p_{n}}{q_{1}} \frac{\partial_{q_{n}}}{\partial_{p_{n}}}+\frac{I}{q_{1}} \frac{\partial_{q_{n}}}{\partial_{I}}=0 \\
& e_{11}+e_{12}+\ldots+e_{1 n}+\eta_{1}=0 \\
& \sum_{k=1}^{n} e_{i k}+\eta_{i}=0
\end{aligned}
$$

The third nature of demand function is symmetry. It means the cross differentiation of the demand function is symmetric. This can be written as: 


$$
\frac{\partial h_{i}(u, p)}{\partial p_{j}}=\frac{\partial h_{j}(u, p)}{\partial p_{i}}, \text { where } i \neq j
$$

if

$\mathrm{S}_{i j}=\frac{\partial h_{i}}{\partial p_{j}}=\frac{\partial h_{j}}{\partial p_{i}}=\mathrm{S}_{j i}$

and

$\mathrm{h}_{i}=\frac{\partial C}{\partial p_{j}}$

thus, by the Young's theorem

$$
\begin{aligned}
& S_{i j}=\frac{\partial^{2} C}{\partial p_{i} p_{j}}=\frac{\partial^{2}}{\partial p_{j} p_{i}}=S_{j i} \\
& \frac{\partial h_{i}}{\partial p_{j}} \frac{p_{j}}{q_{i}} \frac{q_{i}}{p_{j}} \frac{p_{i}}{I} \frac{I}{p_{i}}=e_{i j} W_{i} \frac{I}{p_{i} p_{j}} \\
& S_{i j}=S_{j i} \\
& W_{i} e_{i j}=W_{j} e_{j i} \\
& \frac{1}{w_{i}} e_{i j}+\eta_{i}=\frac{1}{w_{i}} e_{j i}+\eta_{j} \\
& e_{i j}=\frac{W_{i}}{W_{j}} e_{j i}+\left(\eta_{j}-\eta_{i}\right)
\end{aligned}
$$

Elasticity is utilized to measures the prices and incomes changes to the quantities of goods and services demanded. The elasticity used in this paper refers to Marshallian elasticity that can be expressed as:

$$
e_{x, p x}=\frac{\Delta x / x}{\Delta p_{x} / p_{x}}=\frac{\Delta x}{\Delta p_{x}} \cdot \frac{p_{x}}{x}=\frac{\partial x}{\partial p_{X}} \cdot \frac{p_{X}}{x}
$$

Where $e_{x, p x}$ is the price elasticity of demand, $\Delta \mathrm{x} / \mathrm{x}$ is the change in quantity demanded of goods $x, \Delta p_{x} / p_{x}$ is the change in price of goods $x . e_{x, p x}$ is expected to be negative; $e_{x, p x}=0$ is perfectly inelastic; $0<e_{x, p x}<1$ is inelastic; $e_{x, p x}=1$ is unit elastic; $e_{x, p x}>1$ is elastic.

$$
e_{x, p y}=\frac{\Delta x / x}{\Delta p_{y} / p_{y}}=\frac{\Delta x}{\Delta p_{y}} \cdot \frac{p_{y}}{x}=\frac{\partial x}{\partial p_{y}} \cdot \frac{p_{y}}{x} \ldots
$$

Where $e_{x, p y}$ is the cross-price elasticity of demand, $\Delta x / x$ is the change in quantity demanded of goods $x$, $\Delta p_{y} / p_{y}$ is the change in the price of goods $y . e_{x, p y}$ could be positive or negative, $e_{x, p y}>0$ means both goods $x$ and $y$ are substitution goods, $e_{x, p y}<0$ means both goods $x$ and $y$ are complementary goods.

$$
e_{x, I}=\frac{\Delta x / x}{\Delta I / I}=\frac{\Delta x}{\Delta I} \cdot \frac{I}{X}=\frac{\partial x}{\partial I} \cdot \frac{p_{y}}{x}
$$

Where $e_{x, I}$ is the income elasticity of demand, $\Delta x / x$ is the change in quantity demanded of goods $x, \Delta I / I$ is the change in income. $e_{x, I}$ could be positive or negative, $e_{x, I}>0$ means goods $x$ is a normal goods, $e_{x, I}<0$ means goods $x$ is an inferior goods, $e_{x, I}>1$ indicates the goods $x$ is a luxury goods.

The fourth nature of the demand function is negativity. Matrix with $n \times n$ dimension that has $\frac{\partial q}{\partial p_{j}}$

elements should have negative semidefinite property. Another demand function's nature is additivity and separability. Additivity means if the utility from consuming certain goods is independent of other goods, then the utility level can be summed up. It can be expressed:

$$
\begin{aligned}
& U=U_{1}+U_{2}+\ldots+U_{m} \\
& U=f\left(q_{1}, q_{2}, \ldots, q_{m}\right)
\end{aligned}
$$

Where $m$ is number of goods.

Separability in the demand function explains that the consumers can divide their income into some parts (groups). For example, a household's consumption can be categorized into some baskets of goods and services regarding the income and preference. This also means the utility of one basket of goods is independent to other baskets of goods.

\section{3) Demand System Models}

In the welfare analysis, the modeling of demand functions is a very important step to examine the households' behavior. The well-known demand function modeling was developed by Stone (1954) based on the consumers' theory. However, there were many demand models that produced by many economists.

Klein \& Rubin (1948) initiated a demand model that generated from the cost of living index that socalled The Linear Expenditure System. Similar to 
other demand models, this model uses adding-up, homogeneity, and symmetry restrictions.

Theil (1975) modified the demand model created by Stone (1954). The demand model developed by Henry Theil is known as the Rotterdam Model. This model differentiates the Stone Model and inserts the budget share in the differentiated equation.

Transcendental Logarithmic Demand System a.k.a Trans Log Model is a model that employs the direct utility function, indirect utility function, and the cost function. Developed by Christensen, Jorgenson, \& Lau (1975), this model is known for its flexibility. This model uses normalized prices to income in its equation.

Deaton \& Muellbauer (1980) developed the demand model based on expenditure function called Almost-Ideal Demand System (AIDS). This model claims that it has some advantages compared with other demand models such as: having firstorder approximation; accommodating homogeneity, symmetry, and adding up restrictions; and having a function that consistent with consumer's budget. In its development, this model had modified into Linear-Approximation Almost-Ideal Demand System (LA-AIDS) concerning the un-linearity of the price index.

In AIDS model, the Engel's curve is assumed to be linear which means the goods consumed by a household are normal goods. However, in reality, there are some inferior goods. Thus, with the existence inferior goods' consumption, the Engel's curve is no longer linear. Banks, Blundell, \& Lewbel (1997) developed the Quadratic AlmostIdeal Demand System (QUAIDS) to allow the Engel's curve assumption to be quadratic.

\section{Demand System for Energy Goods: Empirical Evidences}

The AIDS model is widely used for estimating the demand system of energy goods. The chosen AIDS model is based on various considerations across the countries, for example, the energy goods consumption pattern, energy goods production, the availability of substitution goods, etc.

Gundimeda \& Köhlin (2008) investigated the income elasticity of demand for energy goods in India using LA-AIDS demand model. They utilized the microdata of approximately 100,000 households all over India, and they also divided the households into different locations, urban and rural areas by different income groups.

Yii, Geetha, \& Chandran (2017) utilized the LA-AIDS to estimate the elasticity of petrol, diesel, electricity, and LPG in Sabah Malaysia. They found that the low-income households are the group that possesses the highest cost of electricity's overconsumption. Moreover, petrol and diesel were proven to be price elastic whereas electricity and LPG were inelastic.

Bazzazan, Ghashami, \& Mousavi (2017) examined the electricity for electricity in Iran using AIDS model. The result was that electricity in Iran, from 1991 to 2012, was the necessity energy goods. This result was found in both rural and urban areas in Iran and encouraged households to be more efficient in the electricity consumption.

Jin \& Zhang (2013) used the monthly microdata from households in Beijing from 2002 to 2009 to calculate the elasticity of residential electricity demand for different income groups. By using combined AIDS and the Linear Double-Logarithmic (LDL) method, they found that the price elasticity of electricity was almost equal to 1 (unit elastic). They suggested that tariff adjustment is important as a policy recommendation. Therefore, the conditional electricity subsidy should be applied.

In Indonesia, Bhakti (2011) investigated the price elasticity, income elasticity, and cross elasticity of energy goods in Java. By applying the LinearApproximation AIDS (LA-AIDS) in 2007 to 2010 Susenas data, she found that all analyzed energy goods had an income elasticity of more than one while all of the price elasticity was negative.

More research that uses AIDS model as well as a combined model to estimate the demand function for energy goods could be found outside Indonesia, but only a few papers employed this method in Indonesia. Therefore, to fill the lack of available research on this particular topic, this paper aims to investigate the elasticity of energy goods in Tabalong Regency using combined LA-AIDS and QUAIDS model in 2016.

\section{MeThoD}

\section{A. Data Selection}

This paper utilized the Susenas data in a scope of Tabalong Regency in 2016. In 2016, BPS of Tabalong Regency conducted Susenas in March and September for regency and national estimation respectively. BPS Tabalong surveyed 555 households in March 2016 as samples. However, some households did not consume some energy goods in the period of the survey. Therefore, to avoid undefined value in the demand model (which is using ln), we choose three main energy goods consumed in 2016 (electricity, premium, and LPG). Eventually, the numbers of households in the model are 387.

To expand the analysis, 387 households will be divided into two groups, the top 60\% (255 households) and the bottom $40 \%$ (132 households) of the income groups. The groups' income derived from grouping the households' income from the highest to the lowest, and sorted it into ten deciles, 
the households in the upper deciles (first to the sixth) are grouped into the top $60 \%$ of the income class. The rest are combined into the bottom $40 \%$ of the income class.

\section{B. Model Specification}

This paper employs both the AIDS and QUAIDS model, depends on the primary result of the analysis. The value of $\lambda i$ determines the form of the model. If $\lambda \mathrm{i}$ is statistically equal to zero, then the QUAIDS model becomes AIDS model, and vice versa (Widarjono, 2016).

The QUAIDS model in this paper can be written as:

$$
\begin{aligned}
w_{i}= & \alpha_{i}+\sum_{j=1}^{n} \gamma_{i j} \ln p_{j}+\beta_{i} \ln \left(\frac{X}{a(P)}\right) \\
& +\frac{\lambda i}{b(P)}\left(\ln \left[\frac{X}{a(P)}\right]\right)^{2}+u_{i} \ldots \ldots \ldots \ldots
\end{aligned}
$$

where $i$ and $j$ are types of goods, $w_{i}$ is the budget share allocated for goods $i, p_{j}$ is the price for goods $j$, $X$ is the total expenditure of household, $a(P)$ is price index that comes from the equation:

$$
\begin{aligned}
& \ln [a(P)]=\alpha_{0}+\sum_{i=1}^{n} \alpha_{i} \ln p_{i} \\
& +0.5 \sum_{i=1}^{n} \sum_{j=1}^{n} \gamma_{i j} \operatorname{lnp}_{i} \ln p_{j} \ldots \ldots . . .
\end{aligned}
$$

$b(P)$ is the aggregate price of Cobb-Douglass expressed as:

$$
b(P)=\prod_{i=1}^{n} p_{i}^{\beta_{i}}
$$

If $\lambda_{i}=0$ for all $i$, then QUAIDS model becomes AIDS model that can be written as:

$$
w_{i}=\alpha_{i}+\sum_{j=1}^{n} \gamma_{i j} \ln p_{j}+\beta_{i} \ln \left(\frac{X}{a(P)}\right)+u_{i} \ldots \ldots
$$

To accommodate the demographic variables, which also affect the consumption decision for such energy goods, the demand model is modified in its intercept such as:

$$
\alpha_{i}=\rho_{i 0}+\sum_{k=1}^{m} \eta_{i k} d_{k}
$$

where $d_{k}$ is $k$-th demographic variable.

All in all, the variables included in this paper comprise of:

Expenditures of premium, electricity, and LPG to calculate the budget share in the model; The price of premium, electricity, and LPG faced by each household; Total expenditure of the households; size of the households, education level of the households' head's, location of the households, gender of the households' head's, and age of the households' head's. For the levels of education can be classified as:

- 1 = dropping out from elementary school

- 2-5 = elementary school graduates

- 6-9 = junior high school graduates

- 10-15 = senior high school graduates

- 16-19 = having an undergraduate degree

- 20-21 = having a postgraduate degree The data processing in this paper uses SPSS 15.0 for the cross-tabulation and the Stata package for QUAIDS developed by Poi (2012) to estimate the demand model as well as the elasticities.

\section{RESULTS AND DISCUSSION}

\section{A. Energy Consumption in Tabalong Regency}

As described in chapter 1 , the three main energy goods consumed in Tabalong in 2016 were premium, electricity, and LPG. The percentage of households consumed for the respective energy goods were $88.38 \%, 99.06 \%$, and $73.73 \%$. The summary statistics for the energy goods' demand model can be seen in Table 3 .

Table 3 shows the summary statistics for the variables used in the energy goods demand model. Based on the filtered data, the households had an average of around four family members. The age of households' head was around 45 with the education level of junior high school. Examined from the budget share perspective, the households used the highest proportion of buying premium for their vehicles (by 0.57). The smallest budget share from the three energy goods was for LPG (by 0.14). This indicates that on average, the households had more priority in transportation than cooking, with the electricity became the middle priority.

\section{B. The Demand Model for Energy Goods in Tabalong Regency}

The decision whether the demand model forms in LA-AIDS or QUAIDS depends on whether the Engel curve is linear or not. This can be seen in the significance of $\lambda \mathrm{i}$. In the initial test, the model indicated that for the top $60 \%$ of income group, the $\lambda i$ was statistically significant for most of the $\lambda i$ (the Engel curve is in not in linear form). This means the top $60 \%$ of the income group will be analyzed by QUAIDS. On the other hand, the bottom $40 \%$ of income group did not provide significant $\lambda \mathrm{i}$, all $\lambda \mathrm{i}$ were not statistically significant (the Engel curve 
Table 3.

Summary Statistics of Variables in the Model (n=387), 2016

\begin{tabular}{|c|c|c|}
\hline Variable & Mean & Std. Dev. \\
\hline Household Size & 3.77 & 1.30 \\
\hline Age of Household Head & 44.88 & 11.04 \\
\hline Education Level of Household Head & 8.75 & 5.40 \\
\hline \multicolumn{3}{|l|}{ Use of Energy Goods (in Percent) * } \\
\hline - Premium & 88.38 & \\
\hline - Electricity & 99.06 & \\
\hline - LPG & 73.73 & \\
\hline Premium Price (in Rupiah/litter) & $7,526.70$ & 599.73 \\
\hline Electricity Price (in Rupiah/Kwh) & 632.32 & 287.70 \\
\hline LPG Price (in Rupiah/kg) & $7,912.69$ & $2,951.26$ \\
\hline Total Expenditure (in Rupiah) & $3,477,045.94$ & $2,385,227.14$ \\
\hline Budget Share of Premium & 0.57 & 0.16 \\
\hline Budget Share of Electricity & 0.29 & 0.14 \\
\hline Budget Share of LPG & 0.14 & 0.09 \\
\hline
\end{tabular}

Note: ${ }^{*}$ indicates the data used come from the actual Susenas data $(n=555)$

Source: Author's Calculation

Table 4.

Model Estimation for the Top 60\% of Income Group in Tabalong, 2016

\begin{tabular}{|c|c|c|c|}
\hline \multirow{2}{*}{ Parameter Estimation } & \multicolumn{3}{|c|}{ Dependent Variable Share in the Model } \\
\hline & Premium & Electricity & LPG \\
\hline constant & $1.109 * *$ & -0.0154 & -0.0936 \\
\hline Price of Premium fuel & -0.0364 & 0.0600 & -0.0236 \\
\hline Price of Electricity & 0.0600 & -0.0106 & $-0.0494 * *$ \\
\hline Price of LPG & -0.0236 & $-0.0494 * *$ & $0.0730 * * *$ \\
\hline Households Size & 0.00377 & -0.00266 & -0.00111 \\
\hline Education Level & $-0.00219 *$ & $0.00208^{*}$ & 0.000114 \\
\hline Households' Location & $0.0231 * *$ & $-0.0238 * *$ & 0.000699 \\
\hline Households' head gender & -0.0358 & 0.0208 & 0.0150 \\
\hline Households' head age & -0.000261 & 0.000408 & -0.000147 \\
\hline Households' Expenditure & $-0.174 *$ & $0.136 *$ & 0.0376 \\
\hline
\end{tabular}

Note: ${ }^{* * * * * *}$ indicate significant at $10 \%, 5 \%$, and $1 \%$ respectively Source: Author's Calculation

Energy Goods Demand in Tabalong Regency: 
Table 5.

Model Estimation for the Bottom 40\% of Income Group in Tabalong, 2016

\begin{tabular}{|c|c|c|c|}
\hline \multirow{2}{*}{ Parameter Estimation } & \multicolumn{3}{|c|}{ Dependent Variable Share in the Model } \\
\hline & Premium & Electricity & LPG \\
\hline constant & $0.505^{* * *}$ & $0.382^{* * *}$ & $0.114 * *$ \\
\hline Price of Premium fuel & $0.117^{* *}$ & -0.0205 & $-0.0961^{* * *}$ \\
\hline Price of Electricity & -0.0205 & 0.0436 & -0.0231 \\
\hline Price of LPG & $-0.0961 * * *$ & -0.0231 & $0.119 * * *$ \\
\hline Households Size & -0.000176 & 0.00362 & -0.00344 \\
\hline Education Level & $0.00795 * *$ & -0.00381 & $-0.00414 *$ \\
\hline Households' Location & $0.105^{* *}$ & $-0.123^{* * *}$ & 0.0187 \\
\hline Households' head gender & $-0.149 *$ & 0.0642 & $0.0847^{* *}$ \\
\hline Households' head age & 0.00116 & $-5.57 e-05$ & -0.00110 \\
\hline Households' Expenditure & -0.122 & 0.159 & -0.0372 \\
\hline
\end{tabular}

Note: ${ }^{* * *, * * *}$ indicate significant at $10 \%, 5 \%$, and $1 \%$ respectively

Source: Author's Calculation

is assumed linear). Therefore, the bottom $40 \%$ of income group will be examined using LA-AIDS.

On the top $60 \%$ of income group, among all variables involved in the premium fuel consumption, only education level, households' location, and households' expenditure that significantly affected demand for premium fuel. For electricity demand, the same variables as in the premium fuel demand involved. The price of LPG became the additional variable that also affected the demand for electricity. For the LPG demand, only two variables that significantly affected: the price of electricity and the price of LPG. Table 4 shows that for the households in the top $60 \%$ of income group, the demographic variables such as gender and age of households' head did not affect the demand for all energy goods. Compared with the Table 4, which provides QUAIDS model estimation, table 5 exhibits the LAAIDS model demand estimation particularly for the households in the bottom $40 \%$ of income group. Table 5 shows that for the demand for premium fuel, five variables were significant: the price of premium, the price of LPG, education level, households' location, and the gender of households' head. However, for electricity demand, only one variable affected significantly, which was households' location. For LPG, the variables that significantly affected the demand were similar to the premium's

Table 6.

Price and Income Elasticities of the Top 60\% of Income Group for Energy Goods in Tabalong, 2016

\begin{tabular}{llcc} 
& \multicolumn{3}{c}{ Elasticity } \\
& Parameter & Electricity & LPG \\
\cline { 2 - 4 } Price of Premium fuel & & 0.02 & -0.07 \\
\hline Price of Electricity & -0.93 & -0.90 & -0.13 \\
\hline Price of LPG & 0.01 & -0.29 & -0.44 \\
\hline Households' Expenditure & -0.34 & 1.02 & 1.08 \\
\hline
\end{tabular}

Source: Author's Calculation 
Table 7.

Price and Income Elasticities of the Bottom 40\% of Income Group for Energy Goods in Tabalong, 2016

\begin{tabular}{|c|c|c|c|}
\hline \multirow{2}{*}{ Parameter } & \multicolumn{3}{|c|}{ Elasticity } \\
\hline & Premium & Electricity & LPG \\
\hline Price of Premium & -0.78 & -0.03 & -0.17 \\
\hline Price of Electricity & -0.11 & -0.87 & -0.09 \\
\hline Price of LPG & -0.57 & -0.12 & -0.21 \\
\hline Households' Expenditure & 0.99 & 1.07 & 0.91 \\
\hline
\end{tabular}

Source: Author's Calculation

case with the absence of households' location as the significant variable. Regarding the demographic variables in the LA-AIDS model, households' size and households' head age were not significant in the demand for all energy goods in the model.

Table 6 provides the Marshallian price and income elasticities for the three energy goods in Tabalong 2016 particularly for the top $60 \%$ of income group. The own-price elasticities were all negative as expected. Among three energy goods in table 6, the premium fuel had the biggest elasticity followed by electricity and LPG. For the income elasticity of demand, all three energy goods were positive with electricity and LPG had a value more than one. Regarding these figures, the electricity and LPG were considered to be the secondary/ luxury goods for the households in the top $60 \%$ of the income group. This also indicates that the households in this income group tend to consume more electricity and LPG with the increase in their income (for example by buying more electronic goods or raw foods to cook). Premium fuel is considered as the necessary goods since its income elasticity was 0.97 (less than 1).

Table 7 shows the Marshallian price and income elasticities for the three energy goods in Tabalong 2016, particularly for the bottom $40 \%$ of income group. The own-price elasticities were all negative in 2016. In table 7, electricity had the biggest elasticity followed by premium fuel and LPG. For the income elasticity of demand, all the three energy goods were positive with only electricity had a value more than one. Electricity was considered to be the secondary/luxury goods for the households in the bottom $40 \%$ of the income group whereas premium and LPG are the necessary goods.

\section{Conclusion}

This paper investigates the demand system for three main energy goods in Tabalong Regency 2016 using Susenas data. The initial step was to determine the suitable demand model for two income groups. The second step was to build the demand model using either LA-AIDS or QUAIDS. Eventually, the elasticities could be calculated from the demand model. This paper produced the following conclusions.

Among five energy goods consumed in Tabalong Regency in 2016 such as Pertamax fuel, premium fuel, electricity, LPG, kerosene, and ADO; most of the households in Tabalong consumed premium fuel, electricity, and LPG. The percentage of households consumed those energy goods were $88.38 \%, 99.06 \%$, and $73.73 \%$ respectively. For the premium fuel, the highest consumption was in the rural area by $61.64 \%$ while the highest consumers were in the top $60 \%$ of the income group (64.47\%). For electricity, most consumption was in the rural area by $61.36 \%$ whereas the highest consumers were in the top $60 \%$ of the income group (64.61\%). LPG consumption mainly in the rural area by $55.57 \%$ and the most consumers came from the top $60 \%$ of the income group. These figures indicate that the top $60 \%$ of the income group was the main consumer of the energy goods in Tabalong 2016. In other words, this income group received the energy subsidy for the most. However, for the electricity, the government already adjusted the subsidy scheme by removing the subsidy for the households that using 900VA (volt-ampere) or more in their houses. For the households that use 450VA voltage in their house, the government continues to provide the subsidy as they are considered as a poor household. The Government also needs to be concerned with adjusting the other energy goods' price such as premium fuel and LPG since the main beneficiaries come from the top $60 \%$ of the income group. However, this policy should be taken carefully considering the households in the bottom $40 \%$ of the income group used these energy goods as the necessity goods (could be seen in the income elasticity of demand).

To obtain the income and price elasticities of 
demand for the energy goods, the estimation results of the demand system model were utilized in this paper. This paper divided the analysis into two parts based on the households' income group. The first part was about the demand system analysis using QUAIDS for the top 60\% of the income group. The result provided the evidence that the households in this income group considered the electricity and LPG as secondary/luxury goods. A $1 \%$ increase in their income will be followed by more than $1 \%$ increase in those goods' consumption. Although the income elasticity of demand for premium fuel was almost one (0.97), these energy goods were classified as the necessary goods. For the own-price elasticity, premium fuel became the energy goods that had the highest elasticity by -0.93 . This high elasticity also indicates that the top $60 \%$ of the income group possessed an ability to shift to other substitution goods such as Pertalite fuel and Pertamax fuel when the price of premium fuel increases. However, it needs more consumption's data from Pertalite fuel and Pertamax fuel to analyze this hypothesis using cross-price elasticity.

The second part of the demand analysis was focusing on the bottom $40 \%$ of the income group. This income group utilized the LA-AIDS model. The estimation result using LA-AIDS model suggested that the households in this income group considered the electricity as secondary/luxury goods while premium and LPG were considered as necessity goods. For the own-price elasticity, electricity had the biggest elasticity for this income group (by-0.87). This means, increasing $1 \%$ in the electricity price will decrease the electricity demand (consumption) by $0.87 \%$. Despite its biggest elasticity, the ownprice elasticity of electricity in the bottom $40 \%$ of income group was smaller than the elasticity in the top $60 \%$ of the income group $(-0.90)$. Overall, the own-price elasticity in the bottom $40 \%$ of the income group had smaller values compared with the top $60 \%$ of the income group. This reality indicates that the demands of energy goods in the poorer households were less elastic. The increasing price of energy goods (reducing of the energy subsidy) will be burdened more by the poorer households. Thus, in a wider scope, the government needs to formulate the conditional energy subsidy to protect the poor households.

This paper also accommodated the impact of the demographic variables on the demand for the energy goods (on the budget share). Based on the significance, only the education level of households' head and households' location affected the households' decision to consume energy goods in both income groups. The interpretations were mixed since the sign of coefficients were different for both income groups. Education level negatively affected the premium consumption in the top $60 \%$ of the income group. The higher education level of the households' head, the lower the possibility to consume premium fuel. This can be assumed that higher education would bring higher income that can lead to decreasing consumption of premium fuel and higher consumption to either Pertalite fuel or Pertamax fuel. On the other side, the higher education in the bottom $40 \%$ of the income group would bring the possibility of higher income that can lead to the higher access for having vehicles. Different from the top $60 \%$ of the income group, the bottom $40 \%$ households tend to consume premium fuel (this can be seen on the higher income elasticity of demand for premium fuel for the bottom $40 \%$ of the income group).

The households' location had the same coefficient signs in the demand model for both income groups. The positive sign of the coefficient on the premium meant that the urban area (code 1) had the smaller probability to allocate more budgets to consume premium fuel while the rural area (code 2) had a bigger chance. LPG had a negative sign on the coefficient which meant the urban area had the bigger probability to allocate more budgets to consume LPG.

The significant effects of those demographic variables on the demand for energy goods proved that the energy policy should concern not only the income groups but also the locations and educational background of households' head. In a bigger scheme, the energy policy should consider the geographical and households background. Of course, there are more demographic variables that should be analyzed in the demand model, so the result would be more comprehensive since Tabalong Regency is only a small portion of samples from Indonesia.

This paper has a limitation in term of either the sample size or the number of observed energy goods. Other papers utilize the AIDS-Censored Model (Censored Model is the model that includes the missing values of consumptions for its model) to overcome the incomplete consumption data; however, this paper doesn't accommodate this method since the size of samples are relatively small, thus, it is better to obtain more observations to improve the paper.

\section{ACKNOWLEDGEMENT}

I thank the BPS-Statistics of Tabalong Regency for the access to the Susenas data. I also extend my gratitude for all of the Statisticians in BPS-Statistics Indonesia who involved in the discussion to ensure that this paper is well-constructed. I highly appreciate the feedbacks from the anonymous reviewers. All of the mistakes in this paper are my own responsibility. 


\section{REFERENCES}

Banks, J., Blundell, R., \& Lewbel, A. (1997). Quadratic Engel Curves and Consumer Demand. Review of Economics and Statistics, 79(4), 527-539. http://doi.org/10.1162/003465397557015

Bazzazan, F., Ghashami, F., \& Mousavi, M. H. (2017). Effects of Targeting Energy Subsidies on Domestic Electricity Demand in Iran. International Journal of Energy Economics and Policy, 7(2), 9-17. Retrieved from http://www.econjournals.com/index.php/ijeep/article/view/3997

Bhakti, D. (2011). Permintaan Energi Rumah Tangga di Pulau Jawa. Bogor Agricultural University. Retrieved from http://repository.ipb.ac.id/ handle/123456789/51435

Breisinger, C., Engelke, W., \& Ecker, O. (2012). Leveraging Fuel Subsidy Reform for Transition in Yemen. Sustainability, 4(11), 2862-2887. http:// doi.org/10.3390/su4112862

Christensen, L. R., Jorgenson, D. W., \& Lau, L. J. (1975). Transcendental Logarithmic Utility Functions. The American Economic Review, 65(3), 367-383. Retrieved from http://www. jstor.org/stable/1804840

Dartanto, T. (2013). Reducing Fuel Subsidies and the Implication on Fiscal Balance and Poverty in Indonesia: A Simulation Analysis. Energy Policy, 58, 117-134. http://doi.org/10.1016/j. enpol.2013.02.040

Deaton, A., \& Muellbauer, J. (1980). An Almost Ideal Demand System. The American Economic Review, 70(3), 312-326. Retrieved from http:// www.jstor.org/stable/1805222

Direktorat Penyusunan APBN, \& Direktorat Jenderal Anggaran. (2017). Informasi APBN 2017. Jakarta: Ministry of Finance of the Republic of Indonesia.

Gundimeda, H., \& Köhlin, G. (2008). Fuel Demand Elasticities for Energy and Environmental Policies: Indian Sample Survey Evidence. Energy Economics, 30(2), 517-546. http://doi. org/10.1016/j.eneco.2006.10.014

International Institute for Sustainable Development. (2012). Panduan Masyarakat tentang Subsidi Energi di Indonesia: Perkembangan Terakhir 2012. International Institute for Sustainable Development.

Jin, Y., \& Zhang, S. (2013). Elasticity Estimates of Urban Resident Demand for Electricity: A Case Study in Beijing. Energy \& Environment, 24(78), 1229-1248. http://doi.org/10.1260/0958-
305X.24.7-8.1229

Klein, L. R., \& Rubin, H. (1948). A Constant-Utility Index of the Cost of Living. The Review of Economic Studies, 15(2), 84-87. Retrieved from http:// www.jstor.org/stable/2295996

Mariyono, J. (2017). Determinants of Demand for Foreign Tourism in Indonesia. Jurnal Ekonomi Pembangunan, 18(1), 82-92. http://doi. org/10.23917/jep.v18i1.2042

Nicholson, W., \& Snyder, C. (2011). Microeconomic Theory: Basic Principles and Extensions. Ohio: Nelson Education.

Poi, B. P. (2012). Easy Demand-System Estimation with Quaids. Stata Journal, 12(3), 433-446. Retrieved from http://www.stata-journal.com/ article.html?article=st0268

Rohac, D. (2013). Solving Egypt's Subsidy Problem. Policy Analysis. Cato Institute. Retrieved from https://www.cato.org/publications/policy-analysis/solving-egypts-subsidy-problem

Statistics Indonesia. (2016). Indonesia - Survei Sosial Ekonomi Nasional 2016. Statistics Indonesia.

Statistics of Tabalong Regency. (2017). Tabalong Regency in Figures 2017. BPS-Statistics of Tabalong Regency.

Stone, R. (1954). Linear Expenditure Systems and Demand Analysis: An Application to the Pattern of British Demand. The Economic Journal, 64(255), 511-527. http://doi. org/10.2307/2227743

Sulistio, J., Wirabhuana, A., \& Wiratama, M. G. (2017). Indonesia's Electricity Demand Dynamic Modelling. In IOP Conference Series: Materials Science and Engineering (Vol. 215). IOP Publishing. http://doi.org/10.1088/1757899X/215/1/012026

Theil, H. (1975). Theory and Measurement of Consumer Demand. Amsterdam: North-Holland Pub. Co.

Widarjono, A. (2013). Food Demand in Yogyakarta: Susenas 2011. KINERJA, 17(2), 104-118. http://doi.org/http://dx.doi.org/10.24002/ kinerja.v17i2.374

Widarjono, A. (2016). Modeling Sistem Permintaan untuk Penelitian Ekonomi dengan SAS. Yogyakarta: UPP STIM YKPN.

Yii, K.-J., Geetha, C., \& Chandran, V. V. (2017). Estimating the Elasticity of Energy Over Consumption at Micro Level: A Case Study in Sabah, Malaysia. Energy Procedia, 105, 3571-3576. http://doi.org/10.1016/j.egypro.2017.03.824 